\title{
Assessment of New NKSMg Fertilizer Based on Protein Hydrolysate of Keratin in Pot Experiments
}

\author{
Małgorzata Popko*, Radosław Wilk, Helena Górecka, \\ Katarzyna Chojnacka, Henryk Górecki \\ Department of Advanced Material Technologies, Faculty of Chemistry, Wroclaw University of Technology, \\ Smoluchowskiego 25, 50-372 Wroclaw, Poland
}

Received: 16 January 2015

Accepted: 22 March 2015

\begin{abstract}
We assessed the effectiveness use of the new NKSMg fertilizer on the germination of rapeseed (Brassica napus L. var. napus). The fertilizer was produced on the basis of protein hydrolysate from processing of poultry feathers. The whole process is based on the digestion of feather waste by acidic hydrolysis, adjusting $\mathrm{pH}$ of the reaction medium, and then enriched in select nutrients. The method allows the production of liquid fertilizers that can be used in soil and foliar applications. Pot experiments have shown that the use of NKSMg fertilizer based on protein hydrolysate of keratin had a significant effect on the increase of plant biomass. The contents of nitrogen, phosphorus, potassium, and magnesium in plants increased by 76.2, 5.20, 37.3, and $29.6 \%$, respectively, compared to unfertilized plants. The use of fertilizer also significantly modified the contents of manganese and zinc in tested plants. Technology of production of fertilizers based on protein hydrolysate is currently implemented by Intermag Co., Polish leader in the manufacture of fertilizers, growth stimulators, and other preparations designed for professional agriculture and horticulture.
\end{abstract}

Keywords: fertilizers, feather waste, hydrolysis, rapeseed, pot experiments

\section{Introduction}

The poultry industry is one of the largest and fastest growing agro-based industries in the world [1-5]. Worldwide poultry meat production in 2012 reached more than 100 million tons - one fifth of which was in the United States. European Union annual production of poultry meat was nearly 13 million tons, and average consumption amounted to about 23 kilos per capita per year [6]. Within the last 20 years, the poultry industry has taken over $10 \%$ of meat market share, which now accounts for one third of global meat production. This can be attributed to an increasing demand for poultry meat and also egg

*e-mail: malgorzata.popko@pwr.edu.pl products [1, 4-6]. A global overview of the poultry sector is shown in Table 1.

However, a major problem that the poultry industry is facing is the large-scale accumulation of waste [1, 4, 7]. Daily slaughter of poultry in a large Polish slaughterhouse is shown in Table 2 [8]. The main keratin waste generated by the poultry industry is feathers $[9,10]$. In Poland, about 70,000 tons of this waste is produced annually [11], while on a global scale it is more than 4 million tons [7]. Keratin, a primary component of feathers, is a fibrillar protein resistant to mechanical and chemical treatments due to the presence of a large number of disulphide bonds in its structure. Native keratin is also resistant to the action of typical proteolytic enzymes, such as pepsin, trypsin, and papain. The duration of biodegradation of feathers in the environ- 
Table 1. Global overview of the poultry sector [6].

\begin{tabular}{|l|c|c|c|c|c|c|c|c|c|c|c|c|c|c|}
\hline \multirow{2}{*}{} & \multicolumn{9}{|c}{ Production (000`t) } & \multicolumn{5}{c|}{ Consumption (kg per capita) } \\
\cline { 2 - 16 }$y$ & 1998 & 2002 & 2006 & 2008 & 2010 & 2011 & 2012 & 1998 & 2002 & 2006 & 2008 & 2010 & 2011 & 2012 \\
\hline France & 2.32 & 2.15 & 1.80 & 1.76 & 1.75 & 1.86 & 1.85 & 25.1 & 24.6 & 23.0 & 24.5 & 24.7 & 25.2 & 25.5 \\
\hline Germany & 0.79 & 1.03 & 1.19 & 1.40 & 1.62 & 1.68 & 1.68 & 15.2 & 17.2 & 16.7 & 18.3 & 18.7 & 19.1 & 18.5 \\
\hline Poland & 0.52 & 0.80 & 1.08 & 1.17 & 1.31 & 1.34 & 1.58 & 14.0 & 19.8 & 23.7 & 24.6 & 26.3 & 27.4 & 27.6 \\
\hline Spain & 1.00 & 1.33 & 1.15 & 1.17 & 1.28 & 1.28 & 1.25 & 27.5 & 33.6 & 31.0 & 30.5 & 30.2 & 30.5 & 30.0 \\
\hline UK & 1.53 & 1.54 & 1.54 & 1.46 & 1.57 & 1.56 & 1.61 & 28.0 & 28.9 & 29.8 & 26.0 & 28.6 & 28.5 & 28.7 \\
\hline EU-27 & $8.82^{\wedge}$ & $9.36^{\wedge}$ & $10.5^{\wedge}$ & 11.5 & 12.2 & 12.5 & 12.7 & $21.5^{\wedge}$ & $23.2^{\wedge}$ & $22.1^{\wedge}$ & 23.3 & 23.1 & 23.1 & 23.1 \\
\hline Brazil & $4.99^{*}$ & $7.67^{*}$ & $9.71^{*}$ & $11.5^{*}$ & $12.8^{*}$ & $13.4^{*}$ & $13.3^{*}$ & $26.3^{* *}$ & $34.3^{*}$ & $37.4^{*}$ & $42.1^{*}$ & $48.1^{*}$ & $49.7^{*}$ & $48.5^{*}$ \\
\hline China & 11.2 & 13.3 & 14.3 & 16.0 & 17.5 & 17.7 & 18.0 & nd & $7.30^{* *}$ & $7.80^{* *}$ & $8.80^{* *}$ & $9.10^{* *}$ & $9.40^{* *}$ & $9.80^{* *}$ \\
\hline Japan & 1.21 & 1.23 & 1.37 & 1.37 & 1.42 & 1.38 & nd & nd & $14.4^{* *}$ & $15.5^{* *}$ & $15.2^{* *}$ & $16.4^{* *}$ & $16.6^{* *}$ & $16.9^{* *}$ \\
\hline Russia & 0.69 & 0.94 & 1.62 & 1.99 & 2.55 & 2.90 & 3.08 & 12.2 & $13.0^{*}$ & $17.4^{*}$ & $19.8^{*}$ & $20.7^{*}$ & $21.3^{*}$ & $22.5^{*}$ \\
\hline USA & $15.1^{*}$ & $17.0^{*}$ & $18.9^{*}$ & $19.9^{*}$ & $19.5^{*}$ & $19.7^{*}$ & $19.7^{*}$ & 45.9 & $50.8^{*}$ & $52.3^{*}$ & $52.0^{*}$ & $50.8^{*}$ & $50.9^{*}$ & $49.6^{*}$ \\
\hline World & 62.3 & 75.3 & 83.0 & 92.5 & 99.2 & 102 & 104 & nd & nd & nd & nd & nd & nd & nd \\
\hline
\end{tabular}

^ To 2004: EU-15, ^^ To 2006: EU-25

* Only chicken and turkey meat, ** Only chicken meat nd - No data

Table 2. Daily slaughter of poultry in a large Polish slaughterhouse [8].

\begin{tabular}{|l|c|c|c|c|}
\hline \multirow{2}{*}{$\begin{array}{c}\text { Type of } \\
\text { poultry }\end{array}$} & \multirow{2}{*}{$\begin{array}{c}\text { Daily } \\
\text { slaughter } \\
\text { (pcs) }\end{array}$} & \multicolumn{3}{|c|}{ Waste generated (t) } \\
\cline { 3 - 5 } & Blood & $\begin{array}{c}\text { Mixture of } \\
\text { slaughter wastes* }\end{array}$ & Feathers \\
\hline Chickens & 50 & $6-7$ & 15 & $13-15$ \\
\hline Geese & 35 & 6 & 15 & 4 \\
\hline Ducks & 35 & 6 & 15 & 4 \\
\hline
\end{tabular}

*Bones, skin, blood, intestines, raw feather, adipose, and muscle tissue

ment is from two to three years, which is a serious ecological problem $[9,10,12]$. In addition, a limited number of disposal companies, affecting the low competitiveness of the market and the lack of alternative solutions for reducing the amount of animal by-products for poultry producers, contributes to the persistence of the price of their purchase at the level of $€ 100$ per ton. For a medium-sized poultry slaughterhouse, producing 20-30 tons of waste per day, this costs about $€ 1$ million annually [13].

The occurrence of the epidemic of bovine spongiform encephalopathy (BSE) has led to the introduction of a series of legal regulations in order to limit the use of processed animal protein in the feeding of livestock. The first ban, introduced in 1988 in the UK, referred to the use of meat and bone meal deriving from ruminants in cattle nutrition. In 1994 a ban on cattle, sheep, and goat feeding was introduced regarding meat and bone meal from mammals. In 2001 the use of processed animal protein in feeding of livestock intended for the production of raw materials and food products of animal origin was totally halted
(Regulation (EC) No. 999/2001). An exception was fish meal, which was permitted for the feeding of animals other than ruminants. In the following years more precise legal acts regarding bans on the use of products of animal origin in nutrition of livestock were introduced (Commission Regulation (EC) No. 808/2003, Commission Regulation (EC) No. 1234/2003, Regulation (EC) No. 1069/2009, Commission Regulation (EU) No. 595/2010, Commission Regulation (EU ) No. 142 /2011) [14, 15].

In view of environmental protection and applicable laws as well as the high cost of disposal, and also the prevention of the waste of valuable organic matter, it is necessary to develop an effective feather waste management that is safe for the environment and economically viable.

This paper presents a method of feather waste processing for the fertilizer NKSMg and assessment of its effect for the plants (rapeseed) in pot experiments.

\section{Materials and Methods}

\section{Production of Fertilizer}

The basis for the production of fertilizer was feather waste, which was obtained from a Polish poultry slaughterhouse. Before hydrolysis the material was washed in deionized water, dried, and comminuted.

The method of producing NKSMg fertilizer is based on digestion of feather waste in $30 \%$ sulfuric acid. The process is carried out for four hours at $80^{\circ} \mathrm{C}$. As a result of hydrolysis the mixture of short peptides and amino acids is obtained. The next step of the process is $\mathrm{pH}$ regulation to 6 with magnesium oxide, and then adding urea and potassi- 
um sulphate. This method enables the production of liquid fertilizers that can be used for both soil and foliar application.

The method is protected with a block patent whose right to dispose of the know-how is Wroclaw University of Technology (Poland) [16-18].

\section{Testing Fertilizer on Plants}

Pot experiments were conducted in Swojec Experimental Station at the University of Environmental and Life Sciences in Wroclaw. Tests were performed at the Wroclaw University of Technology.

The objective of the studies was to determine the effect of NKSMg (8:1:2:0.5) fertilizer based on protein hydrolysate, referred to in this article as Fertilizer FH, on the germination of plants. The tests were carried out on rapeseed (variety Monolith). Fertilization was applied 14 days before sowing plants.

The substrate for growing plants was soil of light loamy sand with low organic matter content. It was characterized by acidic $\mathrm{pH}$ and low levels of soluble forms of potassium, high content of phosphorus, and very high magnesium. The contents of macro- and micronutrients in the soil were not modified before the beginning of the study. In order to improve the properties of the soil, $\mathrm{pH}$ was adjusted by incubating with the addition of calcium carbonate at a dose determined on the basis of a single hydrolytic acidity. The experiment was conducted in pots with a capacity of 0.5 $\mathrm{kg}$ of soil, and the bottoms of the pots were lined with a layer of gravel aerated by a vertical drain. Time of plant vegetation in the experiment was established so that the period of nutrient uptake from fertilizers was about three weeks.

The fertilizing effect of the product on the basis of protein hydrolysate was compared to the control object (unfertilized) and the two most commonly used nitrogen fertilizers: ammonium nitrate and urea. Cultivated plants were fertilized with a nitrogen dose of $0.4 \mathrm{~g} \mathrm{~N}$ per $\mathrm{kg}$ of soil. Fertilizers were applied (in solution form after dilution with water to a volume of $20 \mathrm{~cm}^{3}$ ) on the entire surface of the soil in the pot, and then watered with $50 \mathrm{~cm}^{3}$ of distilled water. Tests were carried out in quadruplicates.

To obtain the highest biomass and nutrient uptake, plants were sown at high density, with 40 pieces of rapeseed per pot. However, due to the very uneven emergence of plants, thinning was conducted, which left in the pots 18 of strongest plants. During the incubation of soil with a deacidifying substance and tested fertilizers, and also during plant growth, soil moisture was maintained at $60 \%$ of field water capacity. A collection of rapeseed occurred on the day 20 after the emergence of plants.

\section{Analytical Methods}

Feathers were subjected to analysis of elemental composition. Nitrogen was determined by the Kjeldahl method, mercury by atomic absorption spectrometry (AMA-254, Altec), and other macro-and micronutrients and toxic ele- ments by inductively coupled plasma optical emission spectrometry (Vista MPX, Varian) after digestion in aqua regia.

In order to determine the amino acid composition in the hydrolysate of keratin obtained by digestion feathers, chromatographic analysis was carried out. The analysis was performed on an amino acid analyzer AAA 400 (Ingos).

In the pot experiments, fresh and dry mass of plants was determined and also the analysis of macro-and micronutrients in the biomass was performed. The nitrogen content in the plants was analyzed by the colorimetric method after mineralization in sulphuric/salicylic acid. The content of the other macro- and microelements was determined after dry mineralization of the plant material in a muffle furnace at $450^{\circ} \mathrm{C}$, and after the obtained ash was digested in nitric acid. Phosphorus was determined by the colorimetric method, other components were determined by atomic absorption spectrometry using SpectrAA-220 FS (Varian).

\section{Statistical Analysis}

The statistical analysis of study results was conducted with Tukey's test for the reasonable significant difference (RIR) at the significance level 0.05. The calculations were made using the STATISTICA program version 10.

\section{Results}

Multielemental analysis has shown that the feathers used for the production of fertilizer are a rich source of nitrogen (14.8\%) and sulfur (2.35\%), as well as micronutrients such as iron (203 mg/kg) and zinc (92.8 mg/kg). On the other hand, the content of toxic metals such as arsenic, cadmium, chromium, mercury, nickel, and lead is at an extremely low level. The elemental composition of the used feathers is presented in Table 3.

As a result of performing the hydrolysis process of feathers, a highly mineralized mixture of short peptides and amino acids was obtained. Hydrolysate, which was the base of the fertilizer, contained significant amounts of amino acids such as proline, serine, glycine, leucine, glutamic acid, aspartic acid, valine, and arginine (respectively 35.5, $33.5,31.6,30.4,27.0,24.4,23.8$, and $20.6 \mathrm{~g} / \mathrm{kg}$ ). The detailed content of amino acids in the protein hydrolysate from poultry feathers is shown in Table 4.

The application of all fertilizers tested in the experiment resulted in a significant increase in the accumulation of plant biomass. The use of fertilizer FH increased the fresh mass of plants by $31.4 \%$ and dry mass by $21.3 \%$ compared to the control object (not fertilized). A slightly better effect was obtained only in the case of ammonium nitrate fertilization with an increase of $31.4 \%$ and $27.7 \%$ for fresh and dry mass, respectively, whereas the use of urea resulted in an increase of fresh mass of rapeseed by $24.8 \%$ and dry mass by $14.9 \%$. Compared to the application of fertilizer FH, plant yield was lower by $5.0 \%$ and $5.3 \%$. The resulting yields in the pot experiments are presented in Table 5. 
Table 3. Elemental composition of the feathers.

\begin{tabular}{|c|c|c|c|c|c|}
\hline Macronutrients & Content (\% d.m.) & Micronutrients & Content (mg/kg d.m.) & Toxic elements & Content (mg/kg d.m.) \\
\hline $\mathrm{N}$ & 14.8 & $\mathrm{~B}$ & 3.15 & $\mathrm{As}$ & 4.15 \\
\hline $\mathrm{P}$ & 0.061 & $\mathrm{Cu}$ & 12.0 & $\mathrm{Cd}$ & $<0.187$ \\
\hline $\mathrm{K}$ & 0.056 & $\mathrm{Fe}$ & 203 & $\mathrm{Cr}$ & 1.77 \\
\hline $\mathrm{Ca}$ & 0.168 & $\mathrm{Mn}$ & 14.0 & $\mathrm{Hg}$ & 0.021 \\
\hline $\mathrm{Mg}$ & 0.034 & $\mathrm{Mo}$ & $<1.94$ & $\mathrm{Ni}$ & 2.45 \\
\hline $\mathrm{S}$ & 2.35 & $\mathrm{Zn}$ & 92.8 & $\mathrm{~Pb}$ & 1.81 \\
\hline
\end{tabular}

Table 4. Content of amino acids in the protein hydrolysate from poultry feathers.

\begin{tabular}{|c|c|c|c|}
\hline Amino acid & Content $(\mathrm{g} / \mathrm{kg})$ & Amino acid & Content $(\mathrm{g} / \mathrm{kg})$ \\
\hline Aspartic acid & 24.4 & Leucine & 30.4 \\
\hline Threonine & 13.2 & Tyrosine & 11.4 \\
\hline Serine & 33.5 & Phenylalanine & 16.3 \\
\hline Glutamic acid & 27.0 & Histidine & 3.65 \\
\hline Proline & 35.5 & Lysine & 3.58 \\
\hline Glycine & 31.6 & Arginine & 20.6 \\
\hline Alanine & 18.0 & Cysteine & 11.5 \\
\hline Valine & 23.8 & Methionine & 0.23 \\
\hline Isoleucine & 14.7 & Tryptophan & $<$ LOD* \\
\hline
\end{tabular}

*Limit of detection (LOD): $<50 \mathrm{pmol}\left(0.5 \mu \mathrm{mol} / \mathrm{dm}^{3}\right)$

After the application of fertilizers, in all three variants a significant increase in the content of nitrogen in the tissues of plants cultivated in the experiment was observed (Fig. 1). $\mathrm{N}$ content in plants compared to unfertilized plants increased by $76.2 \%, 57.5 \%$, and $44.5 \%$, respectively, for the fertilizer FH, ammonium nitrate, and urea. The use of fertilizer based on protein hydrolysate also significantly modified the content of potassium and magnesium (Figs. 2 and 3). The content of $\mathrm{K}$ in plants increased from $57.2 \mathrm{~g} / \mathrm{kg}$ (the control object) to $78.5 \mathrm{~g} / \mathrm{kg}$ (increase of $37.3 \%$ ), and $\mathrm{Mg}$ from $3.93 \mathrm{~g} / \mathrm{kg}$ to $5.09 \mathrm{~g} / \mathrm{kg}(29.6 \%)$. Compared to the application of ammonium nitrate and urea, the content of potassium increased by $21.5 \%$ and $20.9 \%$, respectively, while magnesium content increased by $12.6 \%$ and $11.1 \%$. The use of fertilizer FH, ammonium nitrate, and urea also resulted in an increase in the content of phosphorus in plants, respectively by $5.20 \%, 7.87 \%$, and $13.8 \%$ compared to unfertilized plants, but these differences were not statistically significant (Fig. 4).

In Table 6 the average content of microelements in harvested plants depending on the applied fertilizer is presented. Fertilizer FH significantly modified the content of micronutrients such as manganese and zinc in the aerial parts of rapeseed. The use of fertilizer on the basis of feather waste increased the content of Mn from $80.5 \mathrm{mg} / \mathrm{kg}$ (the control object) to $391 \mathrm{mg} / \mathrm{kg}$ (increase of $386 \%$ ), and $\mathrm{Zn}$ from $83.8 \mathrm{mg} / \mathrm{kg}$ to $232 \mathrm{mg} / \mathrm{kg}(177 \%)$. For other experimental objects statistically significant differences also were found in the content of these micronutrients in plants. The average manganese content in rapeseed fertilized with

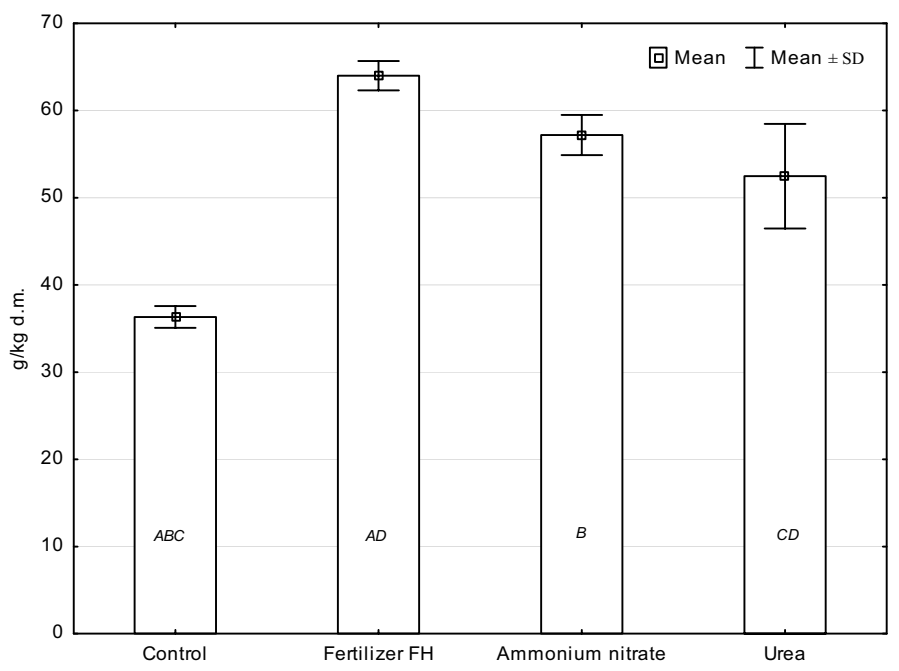

Fig. 1. Content of nitrogen in the harvested plants depending on the type of fertilizer used.

$A, B, C, D$-Values designated with the same letters indicate high significant differences according to Tukey's test $(\mathrm{p} \leq 0.01)$ 
Table 5. Resulting yields in the pot experiments.

\begin{tabular}{|c|c|c|c|c|}
\hline Fertilizer & Repetition & Yield of fresh mass (g) & Yield of dry mass (g) & Part of dry mass $(\%)$ \\
\hline \multirow{4}{*}{ Control (unfertilized) } & 1 & 12.4 & 0.98 & 7.9 \\
\hline & 2 & 11.4 & 0.96 & 8.4 \\
\hline & 3 & 12.4 & 0.93 & 7.5 \\
\hline & 4 & 12.0 & 0.89 & 7.4 \\
\hline \multirow{4}{*}{ Fertilizer FH } & 1 & 15.7 & 1.11 & 7.1 \\
\hline & 2 & 15.2 & 1.11 & 7.3 \\
\hline & 3 & 16.7 & 1.19 & 7.1 \\
\hline & 4 & 15.9 & 1.15 & 7.2 \\
\hline \multirow{4}{*}{ Ammonium nitrate } & 1 & 16.3 & 1.29 & 7.9 \\
\hline & 2 & 16.7 & 1.19 & 7.1 \\
\hline & 3 & 15.0 & 1.11 & 7.4 \\
\hline & 4 & 15.6 & 1.19 & 7.6 \\
\hline \multirow{4}{*}{ Urea } & 1 & 14.7 & 1.03 & 7.0 \\
\hline & 2 & 15.1 & 1.11 & 7.4 \\
\hline & 3 & 14.8 & 0.99 & 6.7 \\
\hline & 4 & 15.9 & 1.18 & 7.4 \\
\hline \multicolumn{5}{|l|}{ Mean } \\
\hline \multicolumn{2}{|l|}{ Control (unfertilized) } & $12.1 \pm 0.47^{\mathrm{ABC}}$ & $0.94 \pm 0.04^{\mathrm{AaB}}$ & $7.8 \pm 0.5^{\mathrm{a}}$ \\
\hline \multicolumn{2}{|l|}{ Fertilizer FH } & $15.9 \pm 0.62^{\mathrm{A}}$ & $1.14 \pm 0.04^{\mathrm{A}}$ & $7.2 \pm 0.1$ \\
\hline \multicolumn{2}{|l|}{ Ammonium nitrate } & $15.9 \pm 0.75^{\text {в }}$ & $1.20 \pm 0.07^{\mathrm{B}}$ & $7.5 \pm 0.3$ \\
\hline \multicolumn{2}{|l|}{ Urea } & $15.1 \pm 0.54^{\mathrm{C}}$ & $1.08 \pm 0.08^{\mathrm{a}}$ & $7.1 \pm 0.3^{\mathrm{a}}$ \\
\hline
\end{tabular}

A, B, C - Values designated with the same letters in a single column indicate high significant differences according to Tukey's test ( $\mathrm{p} \leq 0.01$ )

a - Values designated with the same letters in a single column indicate significant differences according to Tukey's test $(\mathrm{p} \leq 0.05)$

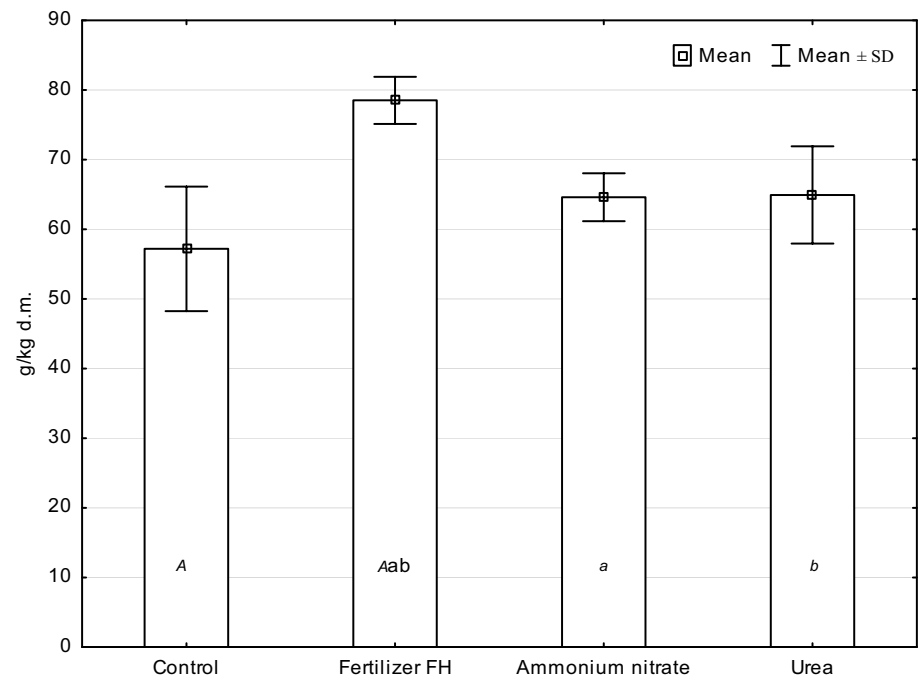

Fig. 2. Content of potassium in the harvested plants depending on the type of fertilizer used.

$A$ - Values designated with the same letters in a single column indicate high significant differences according to Tukey's test ( $\mathrm{p} \leq 0.01$ ) $a, b$-Values designated with the same letters in a single column indicate significant differences according to Tukey's test ( $\mathrm{p} \leq 0.05$ ) 
Table 6. Microelement content in the harvested plants.

\begin{tabular}{|l|c|c|c|c|}
\hline \multirow{2}{*}{ Fertilizer } & $\mathrm{Cu}$ & $\mathrm{Fe}$ & $\mathrm{Mn}$ & $\mathrm{Zn}$ \\
\cline { 2 - 5 } & \multicolumn{3}{|c|}{$(\mathrm{mg} / \mathrm{kg} \mathrm{d} . \mathrm{m})}$. \\
\hline Control (unfertilized) & $8.00 \pm 1.50$ & $128 \pm 11.8$ & $80.5 \pm 23.2^{\mathrm{A}}$ & $83.8 \pm 18.8^{\mathrm{Aa}}$ \\
\hline Fertilizer FH & $8.40 \pm 0.86$ & $155 \pm 38.6$ & $391 \pm 72.6^{\mathrm{ABC}}$ & $232 \pm 15.9^{\mathrm{ABC}}$ \\
\hline Ammonium nitrate & $6.30 \pm 1.05$ & $167 \pm 25.4$ & $150 \pm 28.8^{\mathrm{B}}$ & $109 \pm 4.57^{\mathrm{B}}$ \\
\hline Urea & $6.20 \pm 1.33$ & $150 \pm 30.9$ & $117 \pm 17.2^{\mathrm{C}}$ & $126 \pm 19.1^{\mathrm{aC}}$ \\
\hline
\end{tabular}

Explanations, see Table 5

Table 7. Pot experiments: statistical evaluation of the impact of $\mathrm{NKSMg}$ fertilizer based on protein hydrolysate from poultry feathers for biomass and chemical composition of rapeseed (in comparison to other fertilizers).

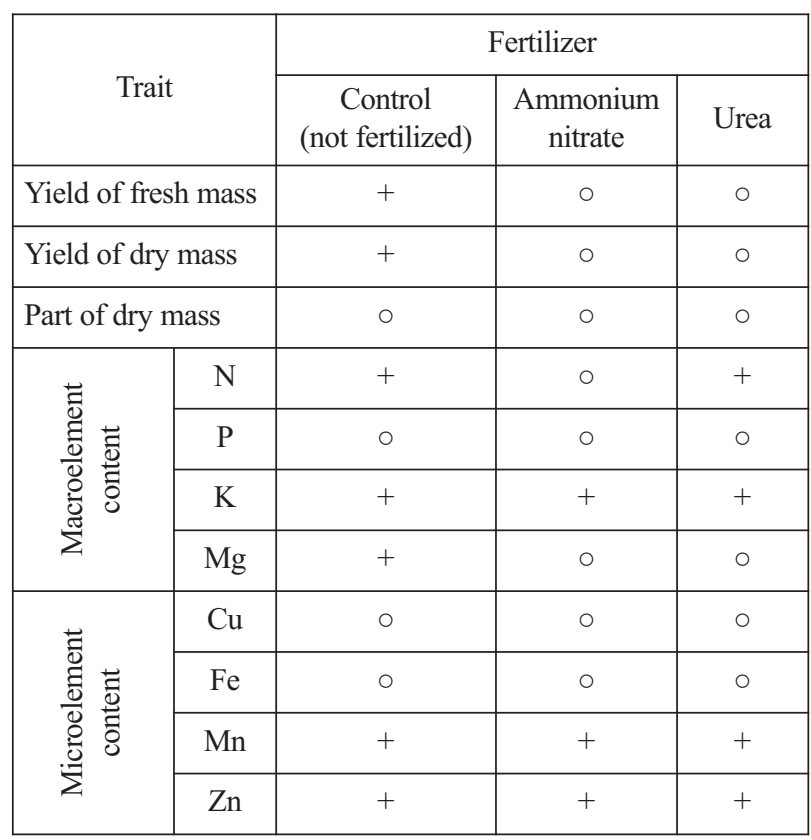

○ Not significant difference, + Significant difference (increase) fertilizer FH was about 161\% higher than for plants fertilized with ammonium nitrate, and $234 \%$ for plants fertilized with urea, while the average zinc content was higher, respectively, by $113 \%$ and $84.1 \%$. The contents of copper and iron were also higher in plants fertilized with fertilizer FH compared to unfertilized plants, respectively by $5.0 \%$ and $21.1 \%$, but these differences were not statistically significant.

\section{Discussion}

The use of feather waste enables the recovery of nutrients and is one of the recommended strategies for dealing with waste [19]. Poultry feathers are a rich source of nitrogen, acting as the main growth factor, and sulfur is often mentioned as a deficient component in agricultural soils. Feather waste is also a source of desired micronutrients in plant cultivation, particularly iron and zinc. The content of toxic metals is at an extremely low level - far ahead of the limit values set by the requirements for organic-mineral fertilizers [20] (Table 3).

Poultry feathers are made of over $90 \%$ keratin proteins $[10,12]$. This is a cheap material to obtain fertilizers based on amino acids, which are well known in the agricultural industry, used primarily as chelates of metal ions.

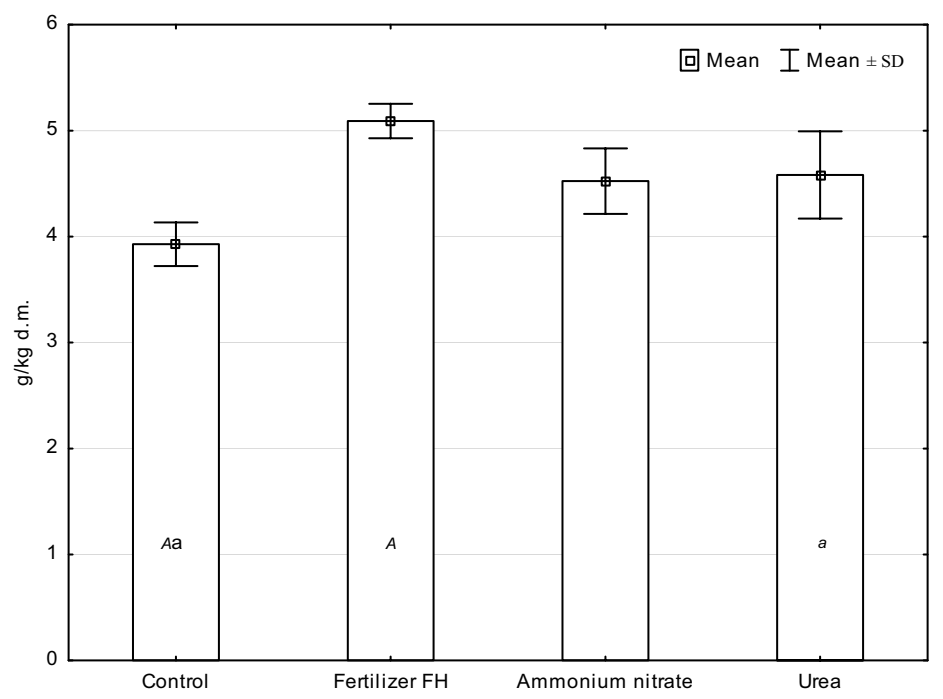

Fig. 3. Content of magnesium in the harvested plants depending on the type of fertilizer used.

$A$ - Values designated with the same letters in a single column indicate high significant differences according to Tukey's test ( $\mathrm{p} \leq 0.01$ ) $a$-Values designated with the same letters in a single column indicate significant differences according to Tukey's test ( $\mathrm{p} \leq 0.05$ ) 


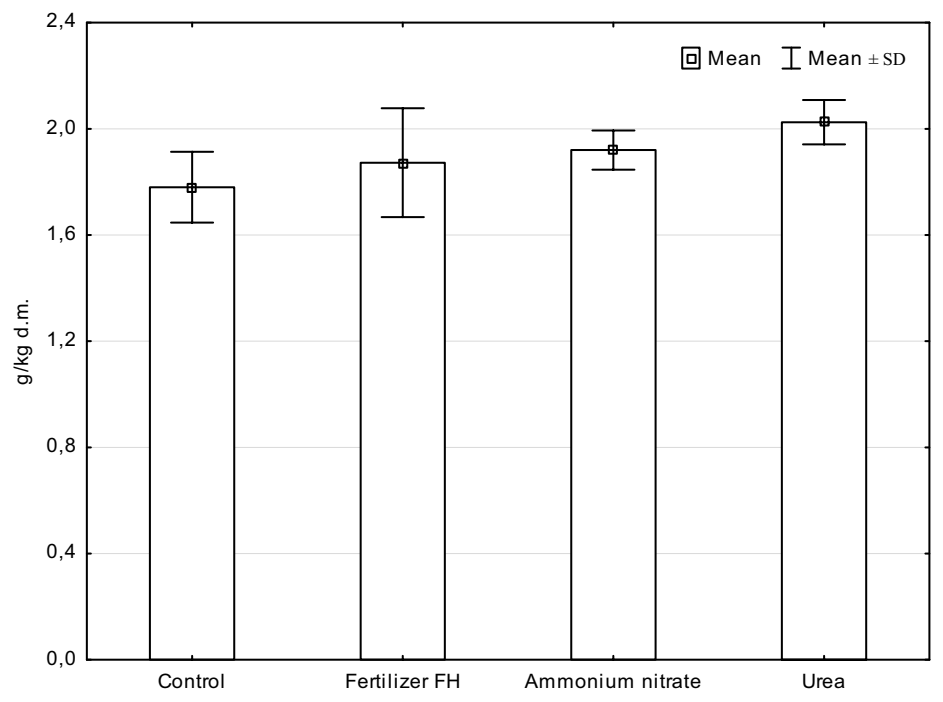

Fig. 4. Content of phosphorus in the harvested plants depending on the type of fertilizer used.

Microelements chelated with amino acids form very small, electrically neutral molecules, which accelerate their absorption and transport within the plant [21-23]. They also act as biostimulators of plant growth. Amino acids are the basic building blocks of protein and fulfill multiple functions in the plant: structural, metabolic, and transport function. Plants are capable of the production of amino acids themselves, but their synthesis is the process that requires large amounts of energy. Therefore, the application of ready-made amino acids allows the plants to save this energy and dynamise the pace of their development or reconstruction, especially in critical times of plant development, such as after transplantation, during flowering and climatic stress (frost, drought), or plant diseases [24-26]. For the production of fertilizer protein hydrolysate of keratin from feather waste was used. Hydrolysate was obtained by digestion of feathers in 30\% sulfuric acid. The total content of amino acids in this hydrolysate was $31.9 \%$ (Table 4 ).

Pot experiments have shown the great effect of the produced NKSMg fertilizer in cultivation of plants. Table 7 presents a summary of statistical evaluation of the impact of fertilizer on the basis of protein hydrolysate for biomass and chemical composition of rapeseed, compared to the control object as well as the used ammonium nitrate and urea. The use of this fertilizer resulted in a significant increase in the accumulation of plant biomass compared to the unfertilized object. Studies have also shown that this fertilizer can be used to supplement the plant with nitrogen, potassium, and magnesium effectively. Plant analysis showed a significant increase in the contents of nitrogen, potassium, and magnesium in the tissues of tested plants compared to the control object, potassium compared to ammonium nitrate, and nitrogen and potassium compared to urea. Furthermore, fertilization significantly increased the content of manganese and zinc compared to all fertilizers used. Increased efficiency of fertilizer FH was associated with the presence of amino acids obtained by hydrolysis of keratin. Amino acids are good chelating agents and they acted as carriers of micronutrients contained in the used soil.

\section{Conclusions}

The presented method of producing liquid fertilizers on the basis of feather waste is the solution for the problem of this waste. It offers many benefits: eliminates the toxic and sanitary problems of feather waste, provides recovery of valuable nutrients from feathers (amino acids, macro- and microelements), enables production of fertilizers (the composition of which is adapted to the needs of the crops), and also allows reuse of industrial sulfuric acid waste.

Currently, registration trials for the fertilizers and also stimulators based on protein hydrolysate of keratin from feathers are carried out in order to introduce them to the market by Intermag Co. (Poland). Tests include physicochemical and microbiological analysis, and also field experiments of agricultural crops (wheat, corn, rapeseed, soy), vegetable crops (tomatoes, lettuce, beet sugar), and fruit crops (apples, cherries). The planned registration is in 2015. Market launch of a new range of fertilizers as well as stimulators on the basis of short peptides and amino acids will allow for the possibility of extending the standard fertilization in order to intensify the yields, and also the application in a situation of shortage of any of the nutrients.

\section{Acknowledgements}

This project was co-financed by the European Regional Development Fund under the Operational Programme Innovative Economy as project No. POIG.01.03.01-02016/12: "The new technology of production of preparations stimulating plants growth from protein hydrolysates." 


\section{References}

1. BOLAN N.S., SZOGI A.A., CHUASAVATHI T., SESHADRI B., ROTHROCK M.J., PANNEERSELVAM P. Uses and management of poultry litter. World. Poultry Sci. J., 66, (4), 673, 2010.

2. JANGWATTANA R., IWAI C.B. Using Azolla pinnata for wastewater treatment from poultry farm. IJERD, 1-2, 23, 2010.

3. BOLU S.A., ADERIBIGBE S.A., OYELAYO L.A. Effects of treated poultry litter on potential greenhouse gas emission and field agronomic performance. Ethiop. J. Environ. Stud. Manag., 7, (6), 677, 2014.

4. FAO. Poultry meat and eggs. Agribusiness Handbook. Rome, 2010.

5. ACMF. Submission to the agricultural competitiveness taskforce. North Sydney, 2014.

6. A.V.E.C. Annual Report. Belgium, 2004, 2008, 2012, 2013.

7. STAROŃ P., BANACH M., KOWALSKI Z. Utilization of waste feathers by thermal treatment. Przem. Chem., 91, (5), 1010, 2012 [In Polish].

8. Internal Data AMI Company (Poland). Mikstat, 2013.

9. ŁABA W., RODZIEWICZ A. Biodegradation of keratinous wastes from poultry industry involving bacteria of genera Bacillus and Sarcina. Acta Sci. Pol. Biotechnol., 3, (1-2), 109, 2004

10. RODZIEWICZA., ŁABA W., SOBOLCZYK J., GRZELAK A., DROZD J. Keratin waste composting with the participation of bacterial vaccine in rotating bioreactor. Inż. Ap. Chem., 48, (3), 95, 2009 [In Polish].

11. MARCINKOWSKA M., WRZEŚNIEWSKA-TOSIK K., SZADKOWSKI M. Paper with the participation of poultry feathers. Przegl. Papiern., 65, 79, 2009 [In Polish].

12. SOBOLCZYK J., RODZIEWICZ A., ŁABA W., BARANOWSKA K. Ecotoxicology in environmental protection. PZITS: Wrocław, pp. 397-402, 2008 [In Polish].

13. GÓRECKI H., GÓRECKA H., CHOJNACKA K., DOBRZAŃSKI Z., ARTMAŃSKA M., BARAŃSKA M., BIEGAŃSKA S. Utilization of poultry wastes to multicomponent fertilizers. Przem. Chem., 89, (4), 360, 2010 [In Polish].
14. WHO. Health, hazards and public debate: Lessons for risk communication from the BSE/CJC saga. Geneva, 2006.

15. WEINER A., PAPROCKA I., GOŁĘBIOWSKA A., KWIATEK K. Prospects of implementation of meat and bone meal into the animal nutrition. Życie Weterynaryjne, 87, (12), 1035, 2012 [In Polish].

16. HOFFMANN J., CHOJNACKI A., GÓRECKI H., HOFFMANN K., GÓRECKA H. Polish Patent No. 197609, 2008 [In Polish].

17. GÓRECKI H., HOFFMANN J., CHOJNACKA K., CHOJNACKI A., GÓRECKA H., HOFFMANN K. Polish Patent No. 205666, 2010 [In Polish].

18. GÓRECKA H., DOBRZAŃSKI Z., GÓRECKI H., CHOJNACKA K., AKSAMSKA I., AKSAMSKI M., ARTMAŃSKA M. Polish Patent No. 216318, 2014 [In Polish].

19. Directive 2008/98/EC of the European Parliament and of the Council of 19 November 2008 on waste and repealing certain Directives. OJEU, L 312, 2008.

20. Polish Regulation of Minister of Agriculture and Rural Development of 18 June 2008 on the implementing some provisions of the Fertilizers and Fertilizing Act. Journal of Laws, No. 119 Item 765, 2008 [In Polish].

21. ALBION. Industry moves to regulate the term "metal amino acid cheated." Research Notes, 3, (3), 1994.

22. ALBION. What exactly are the Metalosate $\AA$ products? Plant Nutrition Newsletter, 1, (2), 2000.

23. JOHANSSON A. Conversations on chelation and mineral nutrition. Aust. J. Grape Wine Res., 583, 53, 2008.

24. MAINI P. The experience of the first biostimulant based on amino acids and peptides: A short retrospective review. Fertilitas. Agrorum. 1, (1), 29, 2006.

25. PALECKIENE R., SVIKLAS A., ŠLINKŠIENE $R$. Physicochemical properties of a microelement fertilizer with amino acids. Russ. J. Appl. Chem., 80, (3), 352, 2007.

26. SEADH S.E., EL-ABADY M.I., FAROUK S., EL-SAIDY AMAL E.A. Effect of foliar nutrition with humic and amino acids under N-levels on wheat productivity and quality of grains and seeds. Egypt. J. Appl. Sci., 23, (12B), 543, 2008. 